hydrolysis of 2-acetylaminofluorene (I). The extent of hydrolysis was determined by diazotizing the resulting free amine (II) and coupling with the disodium salt of 2-naphthol-3,6-disulphonic acid, using a modification of the colorimetric method described by Westfall ${ }^{10}$.

Table 1. Hydrorysis and Carcrnogenicity of Derivatives of

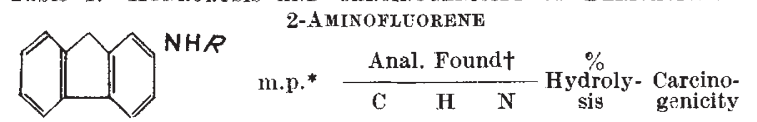

\begin{tabular}{|c|c|c|c|c|c|c|c|}
\hline 1'14 & $\mathrm{CH}_{3} \mathrm{CO}-$ & 194 & & & & 100 & $++t$ \\
\hline $\begin{array}{l}\text { II }{ }^{1,14} \\
\text { III' }\end{array}$ & $\underset{\mathrm{C}_{6}}{\mathrm{H}} \mathrm{H}_{5} \mathrm{CO}-$ & $\begin{array}{l}127 \\
219-220\end{array}$ & & & & $26 \cdot 8$ & $\begin{array}{c}++ \\
+\end{array}$ \\
\hline IV & ${ }_{\mathrm{C}_{6}}^{O} \mathrm{H}_{4} \mathrm{CO}-$ & $219-220$ & $84 \cdot 40$ & $5 \cdot 55$ & $4 \cdot 82$ & $7 \cdot 0$ & \\
\hline$T$ & $\begin{array}{l}m-\mathrm{CH}_{3} \\
\mathrm{C}_{6} \mathrm{H}_{4} \mathrm{CO}-\end{array}$ & $192-193$ & $84 \cdot 37$ & $5 \cdot 67$ & $4 \cdot 85$ & $24 \cdot 8$ & \\
\hline$\sqrt{ } 1$ & $\begin{array}{l}p-\mathrm{CH}_{3} \\
\mathrm{C}\end{array}$ & $217-218$ & $84 \cdot 22$ & $5 \cdot 64$ & $4 \cdot 63$ & $22 \cdot 6$ & \\
\hline & $\mathrm{C}_{6} \mathrm{H}_{4} \mathrm{CO}-$ & $298-299$ & & & & $92 \cdot 7$ & \\
\hline VIII & $\mathrm{CO}^{-}$ & $188-189$ & & & & $53 \cdot 0$ & ++ \\
\hline $1 X^{4,16}$ & $\begin{array}{l}p-\mathrm{CH}_{3}- \\
\mathrm{C}_{6} \mathrm{H}_{4} \mathrm{SO}_{2}\end{array}$ & $160-161$ & & & & $4 \cdot 9$ & 0 \\
\hline
\end{tabular}

* All melting points are uncorrected.
+ Anal. Calc. C, $84.25 ; \mathrm{H}, 5 \cdot 72 ; \mathrm{N}, 4.68$ (Analyses by Rowland Chemical luab.)

The results (Table 1 ) show that there is a consider able difference in the ease of hydrolysis in vitro. The acetyl derivative ( $\mathrm{I}$ ), is the most easily hydrolysed of the compounds studied. 'This is closely followed by the phthaloyl (VII). The tosyl is hydrolysed to the least extent.

It is known that I is very carcinogenic while III is only slightly active ${ }^{11}$. It might be predicted that any 2 -aminofluorene derivative which is hydrolysed to the extent of about 50 per cent or more under the conditions of this experiment would be quite carcinogenic. Thus, the phthaloyl derivative, VII, would be expected to be as carcinogenic as I or II, while the glycyl derivative (VIII) would be moderately active. The $m$ - and $p$-toluoyl derivatives should be compar. able to the benzoyl derivative (III) and have a much lower carcinogenicity than I or II. The tosyl derivative (IX) is non-carcinogenic ${ }^{12}$. The $o$-toluoyl derivative (IV) is hydrolysed to only a slightly greater extent, 7.0 versus 4.9 per cent. It is predicted that this will have little detectable activity.

To test these carcinogenicity predictions, one of the previously untested compounds, 2-glyeylaminofluorene (VIII)* was administered by stomach tube (3 $\mathrm{mgm}$. in $1 \mathrm{ml}$. 1 per cent methylcellulose 5 times weekly for 20 weeks) to young adult male Wistar rats. Six of 20 rats so treated developed cystic cholangiomas, with the first tumour appearing at 57 weeks. In a group of 23 rats receiving the same dose of $I$, 10 rats developed liver tumours; the first tumour was found at 29 weeks. Thus, the latent period for liver carcinogenesis by VIII is practically twice that of I. As predicted by the hydrolysis data, VIII is a carcinogen having a moderate activity compared to $\mathrm{I}$.

A study of the relative carcinogenicities of $I V, V$, VI and VII is being made by Dr. H. P. Morris of the National Cancer Institute.

We are grateful to Charles J. Osterholt, jun., and Martin Nemerow for technical assistance and to L. H. Rombach and I. R. MacGregor for a sample of compound VIII. This work was supported by research grants $C-1356$ and $C-1066$ from the National

${ }^{*}$ In their review ${ }^{2}$ Weisburger and Weisburger state that carcinogenicity data on this compound have been published by Hirs (ref. 13). However, the compound synthesized by Hirs and tested by Twombly
Cancer Institute, National Institutes of Health, U.S. Public Health Service.

Mary F. Argus

Francis E. RaY

Cancer Research Laboratory,

University of Florida,

Gainesville, Florida.

I Wilson, R. H., DeEds, F., and Cox, A. J., Cancer Res., 1, 595 (1941) Weisburger, E. K., and Weisburger, J. H., in Vol. 5 'Advances in Cancer Research', edit. by Greenstein, J. P., and Haddow, A. 361 (Academic Press Inc., New York, 1958).

Newell, M. P. (in preparation)

Ray, F. E., and Argus, M. F., Cancer Res., 11, 783 (1951).

, Weisburger, J. H., and Weisburger, E. K., Cancer Res. $10,620(1950)$.

Weishurger, $\mathrm{H}$ Weisburger, $\mathrm{K}$, and Morris, $\mathrm{H}, \mathrm{P}, \mathrm{N}$. Cancer Inst 11, 797 (1951).

Cancer Inst., 11, 797 (1951).

, R., and Peters, J. H., J. Biol. Chem., 211, 63 (1954).

9 Weisburger, J. H., Biochim, et Biophys. Acta 16, 382 (1955)

Westfall, B. B., J. Nat. Cancer Inst., 6, 23 (1945).

12 Morris, H. P. (in preparation). I. Cancer Res. 13, 415 (1953)

is Hirs, C. H. W., $J$. Amer. Chem. Soc., 71, 1893 (1949).

14 Strasburger, J., Ber., 16, 2346 (1883)

15 Rombach, L. H., and MacGregor, I. R., J. Org. Chem., 19, 428 (1954)

${ }_{16}$ Campbell, N., Anderson, W., and Gilmore, J., J. Chem. Soc., 466 (1940).

\section{Changes in the Level of Serum Protein during Treatment of Kwashiorkor}

Changes in the level of serum proteins during the dietary treatment of kwashiorkor have been reported $^{1}$. As these changes appear to be a consistent feature of the recovery process, it was thought desirable to place them on a statistical basis.

Examination of the results of analyses of the serum of some 429 cases of kwashiorkor, before and after treatment in Nigeria, gave the following results :

\begin{tabular}{|c|c|c|}
\hline $\begin{array}{lll}\text { (Means) Total proteins } & \ldots & \\
\text { Serum albumin } & & \end{array}$ & $\begin{array}{c}\text { Before treatment } \\
\text { (gm./100 ml.) } \\
4.27 \pm 0.84 \\
1.7 \pm 0.54\end{array}$ & $\begin{array}{c}\text { Upon recovery } \\
\text { (gm./100 ml.) } \\
6.5 \pm 1.01 \\
3.5 \pm 0.77\end{array}$ \\
\hline $\begin{array}{l}\text { Coefficient of correlation between } \\
\text { total proteins and serumalbumin } \\
\text { Coefficient of correlation between }\end{array}$ & 0.59 & $0 \cdot 73$ \\
\hline total proteins and serum globulins. . & 0.45 & $0 \cdot 48$ \\
\hline
\end{tabular}

It seems, therefore, that the concentration of serum $\gamma$-globulin is independent of the total protein-level during the treatment of kwashiorkor. On the other hand, the imbalance in the relationship between total serum proteins and albumin, in the acute phase of the disease, is corrected during treatment by increasing the concentration of the latter in the direction of restoring the proportionality between the two.

These data may serve as an accurate means of determining the prognosis in cases of $\mathrm{kwashiork}$ or under nutritional care.

My thanks are due to Dr. Collis and Dr. Hills of the University College Hospital, Ibadan, for allowing me to consult their clinical records.

Biochemistry Laboratory,

OrItMBE BAssir

University College, Ibadan. Sept. 8.

${ }^{1}$ Senecal, J., Ann. New York Acad. Sci., 69, 916 (1958).

\section{Oleuropeic Acid: a New Compound from Olea europaa}

WE have recently announced ${ }^{1}$ the isolation of oleuropein from Olea europaea which proved to be a double ester of glucose with protocatechuic acid and a second, as yet undescribed, non-aromatic acid. We have now succeeded in elucidating the structure of this compound-oleuropeic acid. It could be isolated by alkaline hydrolysis of oleuropein with subsequent fractionation of the hydrolysate from. different solvents. 